By HAZEL DEAN

\title{
Size of Cataloging Staffs in Academic Libraries
}

A LTHOUGH some progress has been made in studies of the cost of cataloging, there are not yet available any standard cost data for cataloging in college and university libraries. The present trend toward estimating cost in units of time rather than money seems to offer a promising approach; but, meanwhile, the question has been raised as to whether some objective measure of efficiency can be found by examining the statistics which are ordinarily put into the annual reports of nearly every library.

A recent textbook on college library administration carries the statement that "the size of the technical staff will depend directly upon the number of new acquisitions to be handled within a given period."1 While the technical staff properly includes both the order and catalog departments in a library organized along conventional lines, it is the cataloging process which has received marked attention in recent years because of its alleged disproportionate cost. Therefore, if some normal or typical ratio between the number of yearly acquisitions and the size of the cataloging staff could be determined, it would be useful as a criterion in terms of statistical data easily available to the administrator who is interested in allocating his resources, usually scarce, to the best advantage. Assuming a fair degree of uniformity in organization and in the definition of cataloging, and a certain standardization of quality of cata-

1 Randall, William M., and Goodrich, F. L. D. Principles of College Library Administration. 2 nd ed. Chicago, American Library Association, 1941, p. 140. loging in college and university libraries, it seems reasonable to try to ascertain what the relation is between the size of the cataloging staff and the number of yearly accessions, in terms of volumes and titles.

With this purpose in mind, questionnaires were sent to the eighty or more college and university libraries which were listed in the current American Library Directory as having book collections of more than 150,000 volumes. In addition to the data on the size of the cataloging staff and the number of annual accessions for the year 1943-44, information was sought on some other characteristics which were thought to have relation to the ratio between the above items.

It has often been stated that the cost of cataloging increases more than proportionately with the size of the book collection. Substituting "size of cataloging staff" for "cost of cataloging," one would expect to find some significant relation between the number of persons on the cataloging staff and the number of volumes acquired within a given period.

Aside from the complexity which mere quantity of material brings, there may be a difference in the difficulty of the material to be cataloged in various libraries. This may be due to the varying proportion of foreign books or special kinds of material which some libraries collect. The best quantitative measure of this qualitative difference seemed to be in the percentage of titles for which Library of Congress cards 
could be obtained. The time consumed in cataloging in the individual library depends on this aspect rather than on the actual difficulty of cataloging, which is a problem for the Library of Congress. The number of those books for which printed cards are not available, then, is a factor in measuring the difficulty of cataloging.

Although not directly related to the main purpose of this investigation, the question of the size of the cataloging staff in relation to the size of the total staff is of some interest. Also, the balance between professional and nonprofessional workers on the cataloging staff may be significant. Both of these items were included in the questionnaire. A more complete picture could have been obtained by including the acquisition department and thus getting the balance between the cataloging and the acquisition work, which together make up the technical processes of the library; but this will have to wait for another study.

\section{Some Lack of Uniformity Found}

Originally data were secured from some libraries smaller than the 150,000 volumes mentioned above. However, these were found to have only one or two persons on the cataloging staff, and they were not fully departmentalized; in one case, the other members of the staff assisted with the cataloging, but the more usual situation was found to be that in which the catalogers also did reference work and/or order work. Data from other libraries were not usable for various reasons. One library reported that it was engaged in a complete recataloging operation, and two others that their serials were cataloged by a separate department which also checklisted and accessioned." Another variation which led to the omission of the data from certain libraries involved the use of student assistants in the catalog department. A few librarians reported considerable use of students in this way and decided that it would be misleading to omit them from the statistics. When the ratios were determined, however, it was found that the average number of volumes per cataloger in these libraries was so much lower than the average in the other cases, that it seemed preferable to treat them separately.

\section{Forty-six Libraries Selected}

Of the sixty-two libraries replying to the questionnaire, forty-six were selected as showing enough uniformity in organization to allow statistical comparison. These libraries ranged in size from 170,000 volumes to $1,800,000$ volumes. In the following tables the relation found between the size of the cataloging staff and the yearly number of accessions is expressed in terms of volumes or titles per member of the cataloging staff, as the case may be.

TABLE I

Volumes and Titles Processed Annually (Per Cataloger)

\begin{tabular}{|c|c|c|c|}
\hline \multirow[b]{2}{*}{ Measure } & \multicolumn{2}{|c|}{ Volumes } & \multirow[b]{2}{*}{$\begin{array}{l}\text { Titles } \\
\left(3^{*}\right) \\
\end{array}$} \\
\hline & $\begin{array}{c}\text { As Reported } \\
\text { (I) }\end{array}$ & $\begin{array}{c}\text { As Correct } \\
\text { (2) }\end{array}$ & \\
\hline $\begin{array}{l}\text { Mean } \\
\text { Median } \\
\text { Range }\end{array}$ & $\begin{array}{c}154^{8} \\
1500 \\
608 \text { to } 3421\end{array}$ & $\begin{array}{c}1485 \\
1497 \\
608 \text { to } 247 \text { I }\end{array}$ & $\begin{array}{c}907 \\
833 \\
419 \text { to } 1555\end{array}$ \\
\hline
\end{tabular}

* Data from nineteen libraries.

As reported, the number of volumes included all accessions, whether or not cataloged. Since some libraries do not regularly catalog bound periodicals or government publications, a correction was made for those libraries reporting a certain percentage of accessions not cataloged. (See Table I, Column 2.)

\section{New Titles}

From the cataloging point of view, the number of titles is more significant than the number of volumes; but, of the forty- 
six libraries reporting, only nineteen had available data on new titles. (See Table I, Column 3.)

In order to discover whether the relation between the size of a library and the ratio between the size of the catalog department and the number of yearly accessions was significant, a scatter diagram was made, using the corrected data for volumes per cataloger in relation to the number of volumes in the libraries. No relationship of any significance was found between them. For example, the smallest library had 9I0 volumes of yearly accessions per cataloger and the largest library, 1493, while both the lowest $(608)$ and the highest (247I) number of volumes per cataloger occurred in libraries of over a million volumes. The limited data which were available for number of titles per cataloger revealed no greater evidence of significant relationship with the size of the library. It seems obvious that one must look elsewhere for the explanation of the wide variations in the figures. In general, the variations may be due to (I) differences in the nature of the material cataloged, as to subject and form,

(2) differences in cataloging rules used, (3) differences in personnel or in the administration and organization of personnel, or (4) differences in the number of items for which Library of Congress cards are available.

\section{Library of Congress Cards}

The percentage of titles for which $\mathrm{Li}$ brary of Congress cards were obtained might be expected to give a quantitative measure of the weight to be given to the differences (I) and (2) above, as well as being in itself a cause of variation in the number of volumes processed per cataloger. The two tables in the following column show a breakdown of the results of analyzing these data.
TABle II

Relation between L.C. Cards and Catalogers' Total Production

Percentage of
L.C. cards
90 to 1 co
80 to 89
70 to 79
60 to 69
50 to 59
40 to 49
30 to 39

Number of
Libraries
Reporting
6
9
17
6
5
1
1

Average Number
of Volumes
per Cataloger
1855
1327
1403
1538
1905
700
1402

The corresponding data for the nineteen libraries reporting on the number of new titles may be of interest.

\section{TABLE III}

Relation between L.C. Cards and Numbers of New Titles Cataloged

\begin{tabular}{|c|c|c|}
\hline $\begin{array}{l}\text { Percentage of } \\
\text { L.C. Cards }\end{array}$ & $\begin{array}{l}\text { Number of } \\
\text { Libraries } \\
\text { Reporting }\end{array}$ & $\begin{array}{l}\text { Average } \\
\text { Number } \\
\text { of Titles per } \\
\text { Cataloger }\end{array}$ \\
\hline 90 to 100 & 2 & 845 \\
\hline 80 to 89 & $\begin{array}{l}5 \\
8\end{array}$ & $\begin{array}{l}799 \\
801\end{array}$ \\
\hline $\begin{array}{l}70 \text { to } 79 \\
60 \text { to } 69\end{array}$ & $\begin{array}{l}8 \\
2\end{array}$ & $\begin{array}{r}801 \\
1158\end{array}$ \\
\hline 50 to 59 & 2 & 1412 \\
\hline
\end{tabular}

Table II shows no significant relation between the percentage of L.C. cards obtainable and the volumes per cataloger. Table III shows some evidence of an inverse relation between the percentage of L.C. cards and the number of titles per cataloger. However, the number of libraries reporting on this item is too small to give the figures much validity.

\section{Professional Staff}

Omitting one library, the proportion of professional members of the catalog staffs ranged from 50 per cent to 100 per cent. No further statistical work was done on this subject because it was recognized that in many parts of the country the difficulty of obtaining clerical assistants made the present situation abnormal in this respect. Ordinarily, one would expect to find a 
larger proportion of clerical or nonprofessional workers in the catalog department.

\section{Comparison with Total Staff}

Some study was made of the data concerning the balance between the size of the catalog staff and the total staff. Of course, a proper balance depends on a good many factors, such as the number of school and departmental libraries, centralization or decentralization of cataloging, etc. Since libraries in the professional schools, such as law and medicine, usually catalog their own collections, the data in this study are limited, in the main, to central and departmental libraries. With this limitation, the statistics submitted give a fairly accurate picture of the current situation. Some libraries reported that their total staff had decreased while the catalog staff had remained constant. On the other hand, some reported that the catalog staff had suffered more losses, relatively, than the other departments. One situation seems to offset the other.

In the following table the size of the cataloging staff is shown as a percentage of the total staff.

\section{TABLE IV}

Distribution of Catalog Staff to Total Staff

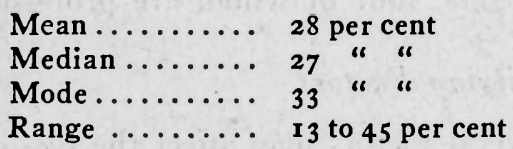

The percentage figure occurring most often, as shown by the above table, was 33 per cent, the case in which the catalog staff was one-third of the total staff. The figures for total staff did not include the separate school or college libraries of the larger universities. An analysis of the statistics of the libraries arranged in order of size of book collection follows.
TABLE V

Percentages of Total Staffs on Cataloging Staffs in Libraries of Various Size-Groups

\begin{tabular}{|c|c|c|c|c|}
\hline $\begin{array}{c}\text { Size of } \\
\text { Library } \\
\text { in Volumes }\end{array}$ & $\begin{array}{l}\text { Number } \\
\text { of } \\
\text { Libraries }\end{array}$ & \multicolumn{3}{|c|}{$\begin{array}{c}\text { Average Size } \\
\text { of Catalog } \\
\text { Staff } \\
\text { (in per cent } \\
\text { of total staff) }\end{array}$} \\
\hline I 70,000-r 99,000 & 7 & 251 & per & cent \\
\hline $200,000-299,999$ & I4 & 29 & “ & \\
\hline $300,000-399,999$ & 7 & 26 & “ & " \\
\hline $400,000-499,999$ & 5 & 25 & “ & \\
\hline $500,000-599,999$ & 5 & 27 & " & \\
\hline $600,000-699,999$ & $\mathbf{I}$ & 40 & “ & “ \\
\hline $700,000-799,999$ & o & - & & \\
\hline $800,000-899,999$ & 2 & 33 & “ & \\
\hline $900,000-999,999$ & $\mathbf{I}$ & 34 & $"$ & \\
\hline$, \infty 0, \infty<0$ and over & 4 & 27 & & \\
\hline
\end{tabular}

This analysis shows that there is a tendency for the number of persons engaged in cataloging to increase more than proportionately with the size of the library. It may be that the rate of growth of the book collection increases as the library grows larger. This would be true if the larger libraries were also the most rapidly growing libraries, relatively to their size. Or it may be that the complexities of organization within the catalog department increase as the library grows larger. Again, it must be remembered that the statistics used in this investigation do not include all of the school and college libraries of the universities.

\section{Student Assistants}

The statistics of those libraries reporting a considerable use of student assistants seemed to confirm the opinion of many head catalogers that there may be no net gain from the use of this type of assistant in the catalog department. Unless their use is confined to alphabetizing cards and labeling books, the results of their work are apt to be unsatisfactory without such supervision by a professional member of the staff as to cancel any gain that might be made. Even if the help of the student 
assistant is gratuitous so far as the annual budget of the department is concerned, the time spent by the professional worker in supervision may be out of proportion to the work accomplished by the student. However, if the students work on a half-time schedule and on a year-round basis, the net gain may be worth considering, particularly now when clerical help is both expensive and scarce. Twelve libraries reported the use of student assistants in the catalog department to be the equivalent of one or more full-time person; but only seven of these gave the actual figures in equivalents of full-time. ${ }^{2}$ The following table therefore includes only seven libraries, ranging in size from 112,000 to 671,000 volumes.

\section{Table VI}

Annual Production per Cataloger in Seven Libraries Which Make Considerable Use of Student Assistants

\begin{tabular}{lcc} 
& \multicolumn{2}{c}{$\begin{array}{l}\text { Volumes per } \\
\text { Cataloger }\end{array}$} \\
& $\begin{array}{l}\text { Including } \\
\text { Students }\end{array}$ & $\begin{array}{c}\text { Omitting } \\
\text { Students }\end{array}$ \\
Measure & 926 & 1821 \\
Mean & 984 & 1575 \\
Median & 627 to 1480 & 1090 to 2400 \\
Range &
\end{tabular}

\section{Summary}

Summing up the results of the investigation in terms of averages we find that in the fiscal year 1943-44 the average ratio between the number of yearly accessions and the size of the catalog staff in forty-six college and university libraries was 1548 volumes per cataloger ; corrected for uncataloged material, 1485 volumes per cataloger. For nineteen of these libraries the ratio of yearly accessions in terms of titles was 907 titles per cataloger. For seven other libraries the number of volumes per cataloger (corrected), including student as-

2 If the report were made in terms of hours, forty hours per week was considered the equivalent of one full-time person. sistants, was 926 , or, omitting students, I821. These latter figures compare unfavorably with the ratios of the forty-six libraries not using students in considerable numbers. The size of the library and the percentage of titles for which L.C. cards were used had no significant relationship to the number of volumes or titles per cataloger. The average size of the catalog staff was 28 per cent of the total staff. In this case there was a significant relationship between the percentage figure and the size of the library, the percentage increasing in libraries over 600,000 volumes until the million mark was reached, and then decreasing. With one exception, the percentage of professional catalogers on the cataloging staff varied from 50 per cent to IOO per cent.

\section{An Example}

How large a cataloging staff will be needed by a library having 12,000 yearly accessions, all of which are to be cataloged? The average ratio of volumes to catalogers being 1485 to $I$, it will be found that approximately eight persons will be needed on the cataloging staff, of whom at least half will be professionals. Comparison with the table given in Mann's textbook ${ }^{3}$ may be of interest. In the latter, an annual output of 12,000 volumes requires nine catalogers, four of whom are professionals.

\section{Qualifying Factors}

Several factors may affect the size of the cataloging staff in relation to the annual accessions. If the proportion of new-titles is large in comparison to the number of volumes, more than the average number of catalogers will be needed. In this connection it should be noted that the average ratio of titles to volumes was about one to

${ }^{3}$ Mann, Margaret. Introduction to Cataloging and the Classification of Books. $2 \mathrm{~d}$ ed. Chicago, American Library Association, 1943. Appendix 2. 
two, or twice as many volumes as titles in the yearly accessions, the ratio increasing with the size of the library. The larger libraries obviously acquire more serial publications than the small ones. The number of duplicate catalogs is another important factor to be taken into consideration in deciding on the size of the catalog department. The more catalogs, the larger the staff required-all other things being equal.

Although it was assumed at the beginning of this study that the organization of the cataloging processes is fairly well standardized in college and university libraries, there are individual differences of some degree, and these would act as qualifying factors on the size of the staff. Those libraries which have separate serial departments which do the cataloging as well as the checklisting, will not need as large catalog departments as they would otherwise, although there may not be any net saving in cataloging time. On the other hand, the catalog department which does accessioning and labeling will need more nonprofessional persons than one not handling these processes. These are such obvious considerations that one need not dwell on them. According to the findings of this investigation, the catalog department using considerable student help will need the equivalent of more persons than one dependent on full-time nonprofessional workers. The question of centralization of cataloging will have to be considered in this connection also. Decentralization will mean fewer persons in the central catalog department, but may increase the total amount of time spent on cataloging throughout the university. The factors of working time, hours per week, and vacations are probably so nearly uniform that they may be disregarded in calculating the staff in this way.

Aside from these qualifications, what factors have caused the wide variations in the number of volumes and titles per cataloger in the institutions studied? Is it possible that due to some cause, such as higher salaries, the climate, or mere chance, the more efficient catalogers are attracted to certain libraries? Or is it not more likely that it is due to more efficient methods and organization of the work within the catalog department or to differences in the quality of the cataloging? Although implied in the above paragraphs, the answers to these questions are really outside the scope of this inquiry, but should receive some consideration from the librarians and head catalogers concerned. 